\title{
Job Satisfaction of Part-time College Teachers in the District of Hooghly, West Bengal
}

\author{
Abhijit Dutta*, Pranab Barman, Dr. Santosh Kumar Behera \\ Department of Education, Sidho-Kanho-Birsha University, Purulia, West Bengal, India \\ *Corresponding author: dutta.dutta91@rediffmail.com
}

Received September 11, 2014; Revised November 20, 2014; Accepted December 10, 2014

\begin{abstract}
In the present study an attempt has been made by the investigators to study the Level of Job Satisfaction of Part-time College Teachers in the district of Hooghly, West Bengal. The investigators used Descriptive Survey method for the present study. The sample consists of 110 Part-time College Teachers from 6 (six) selected General Degree Colleges which are situated in the district of Hooghly, West Bengal. The Purposive sampling technique has been used for the selection of sample. The investigators have developed a tool namely "Teachers' Job Satisfaction Scale" by themselves to measure the Level of Job Satisfaction of Part-time College Teachers on the basis of Seven Important Dimensions that are Working Conditions, Salary Status, Understanding between Colleagues, Recognition by Others, Work Load, Availability of Power and Status and Promotion Opportunities. For the analysis of data ' $t$ ' test has been used in the present study. The overall results indicate that the Level of Job Satisfaction of Part-time College Teachers of the Hooghly District is neither Unsatisfied nor Satisfied i.e. Moderate. And it is also found through the present study that the demographic variables that are Gender, Locality, Stream, Educational Qualification, Teaching Experience and Income have no any significant impact on Job Satisfaction of Part-time College Teachers of the district of Hooghly, West Bengal.
\end{abstract}

Keywords: job satisfaction, part-time college teachers, demographic variables, dimensions of job satisfaction

Cite This Article: Abhijit Dutta, Pranab Barman, and Dr. Santosh Kumar Behera, "Job Satisfaction of Parttime College Teachers in the District of Hooghly, West Bengal.” American Journal of Educational Research, vol. 2, no. 12A (2014): 13-21. doi: 10.12691/education-2-12A-3.

\section{Introduction}

Indian Education system is diversified one in nature in this world. Now Indian Higher Education sector has become the largest in the world in terms of number of institutions and the second largest in terms of students; the sector is already educating and enabling almost 28 million students in nearly 726 universities and 38000 colleges [1]. There are near about 9 lakhs teachers engaged to teach in these universities and colleges in India. And out of 9 lakhs, more than 7 lakhs teachers are engaged at college level to impart higher education [2]. Teachers are working in various modes in our country at higher education level. Few teachers are working as full-time permanent basis, few are full-time contractual basis, and few are part-time basis. For that reason, their salary structure is not also the same. But as the salary is one of the most important determinants of employee's job satisfaction, therefore whose salary is not sufficient to them, they are generally less satisfied with their job. As a result this kind of mentality of teachers affects their overall performance as well as in institutional betterment The employees also share these ideas, believing that the increase of the salaries will absolutely increase the job satisfaction, which will reflect on the motivation to work and raise the level of human performance or the quality of products or services [3].

If we look carefully the condition of higher education system of the state of West Bengal, we can see that there are near about 452 General Degree Colleges and 18 universities are engaged to provide higher education to the students of this state [4]. And now at this moment more than 6000 Part-time teachers are working in these General Degree Colleges in West Bengal [5]. This number of Parttime College Teachers is not low in amount in respect of full-time college teachers who are working at this moment in different degree colleges in West Bengal. Actually most of the colleges are functioning their academic activities by their Part-time college teachers in West Bengal in most of the time [5]. But they are being humiliated by the full-time teachers, governments, authorities in most of cases and deprived from their actual right and dignity. Even their salary status is not sufficient in respect to the full-time college teachers. The salary status of Part-time college teachers has been declared by the West Bengal Government in 2010 that are the teachers with teaching experience of $<4$ years Rs. 7000 - Rs. 9450 , $>4$ years but $<10$ years Rs. 8000 - Rs. 10800 and $>10$ years Rs. 10000 to Rs. 13500 [6]. No other allowances will be admissible to the PTTs except the enhancement @ 5\% of the remuneration, at an interval of three (3) years, after the enhancement done as on 01/10/2010. The college 
authority may allot 10 (Ten) classes/ periods per week to each Part-time Teachers (PTTs) [6].

This is not only the problem of Part-time College teachers, but also they are suffering from so many problems like lack of professional dignity, prestige, professional benefits like other full-time teachers, i.e. promotion, no future incentive, job security, and so on though they are playing the major role in the teaching learning process of their colleges [7]. However, recently the Government of West Bengal has declared and passed a Government Order (G.O) by which the Part-time College Teachers can continue their service upto 60 years like other full-time teachers on the permanent basis [6].

Therefore, as teachers' job satisfaction and professional commitment or performance is closely related to each other, hence it is very necessary to think deeply over the matter of job satisfaction of Part-time College Teachers in order to improve the quality of teaching learning process of higher education in India especially in West Bengal [8].

\section{Statement of the Problem}

The investigators have tried to find out the level of Job Satisfaction of the Part-time College Teachers in the district of Hooghly through the present study. Hence, the present investigators have selected the Title of their research problem in the following manner- "Job Satisfaction of Part-time College Teachers in the district of Hooghly, West Bengal”

\section{Review of Related Literature}

Dishari Gupta (2014) has conducted a study on “A Comparative study of Job satisfaction and Organizational Commitment as work place values among Part-Time Lecturers and Guest Lecturers of Government Aided Colleges in West Bengal”. The purpose of the study was to understand the job satisfaction and organizational commitment levels of part-time and guest lecturers of Government aided colleges in West Bengal. The result of this study shows that there is significant difference in job satisfaction and organizational commitment among Parttime \& Guest Lecturers. The mean value for job satisfaction has been found to be higher for Guest Lecturers whereas organizational commitment is higher in case of Part time Teachers. From the study, it is cleared that the Part time Lecturers are much more committed to their organization, if the variables that are related to their job satisfaction are enhanced, they will perform better and their quality of work life will be enhanced whereas if job security of Guest Lecturers is ensured, then their overall performance and commitment would increase [7].

Manju Malik (2013) has conducted a study on “A comparative Study on Job Satisfaction between Ad-Hoc Basis Teachers and Regular Teachers with reference to Degree Colleges of Kurukshetra” to identify and understand various factors affecting faculty job satisfaction and to compare the job satisfaction of regular basis teachers with ad hoc basis teachers. The results show that the ad-hoc basis faculties are highly dissatisfied regarding salary/leave benefit, job security, research support and facilities, career advancement than the regular basis teachers [9].

Cashwell, Allison L. (2009) has conducted a study on "Factors affecting part-time faculty job satisfaction in the Colorado community college system" to examine factors influencing job satisfaction in the CCCS and, based on those findings, to provide suggestions to administrators charged with developing institutional policies to address specific variables which indicated increased job satisfaction among part-time faculty employees. Using survey responses from part-time faculty teaching at the thirteen community colleges comprising the Colorado Community College System (CCCS), this study identified statistically significant factors associated with job satisfaction and proposed policy recommendations for improving part-time faculty job satisfaction [10].

Florencia López Bóo, Lucia Madrigal \& Carmen Pagés (February, 2009) have conducted a study on "Part-Time Work, Gender and Job Satisfaction: Evidence from a Developing Country" to find out the relationship between part-time work and job satisfaction using a recent household survey from Honduras. In contrast to previous work developed countries, this paper does not find a preference for part-time work among women. Instead, both women and men tend to prefer full- time work, although the preference for working longer hours is stronger for men. Consistent with an interpretation of working part-time as luxury consumption, the paper finds that partnered women with children, poor women or women working in the informal sector are more likely to prefer full-time work than single women, partnered women without children, non-poor women or women working in the formal sector [11].

Brown, James C. (2007) has conducted a study on "Full and part -time employee stress and job satisfaction at two upstate New York colleges" to examine the differences between 227 full-time and part-time (employee status) faculty and staff (employee position) members at two upstate New York colleges and their selfreported levels of stress and their perceptions of job satisfaction. The data suggested that significant differences exist in the area of employee status (full-time versus part-time) in 6 of 12 dimensions of stress: overload, resources and communication, job security, pay and benefits, psychological well-being, and job satisfaction (aspects of the job) [12].

\section{Need and Significance of the Study}

As the focus of the present paper is to find out the level of Job Satisfaction of Part-time College Teachers of the district of Hooghly, West Bengal, therefore we can able to know the actual condition of job satisfaction of Part-time College Teachers through the present study. To conduct this study the present investigators have constructed a Teachers' Job Satisfaction Scale which will be very helpful for other researchers to conduct future researches in the field of Job Satisfaction of Teachers in another State or Country. After all the findings of this study can help the Government, Policy Makers, College authorities as well as the Head of the institutions to take some effective measures or initiatives in order to remove the problems of Part-time college teachers related to their job and try to 
increase the level of job satisfaction of Part-time college teachers of the district of Hooghly, West Bengal for the betterment of higher education in this state.

\section{Objectives of the Study}

The investigators have conducted their study on the basis of following objectives:

a) To find out the level of Job Satisfaction of Part-time College Teachers in the district of Hooghly, West Bengal.

b) To find out the differences between Male and Female Part-time College Teachers with respect to their Job Satisfaction.

c) To find out the differences between Urban and Rural Part-time College Teachers with respect to their Job Satisfaction.

d) To find out the differences between Married and Unmarried Part-time College Teachers with respect to their Job Satisfaction.

e) To find out the differences among the Part-time College Teachers with respect to their Job Satisfaction on the basis of their Age.

f) To find out the differences among the Part-time College Teachers with respect to their Job Satisfaction on the basis of their level of Educational Qualification.

g) To find out the differences among the Part-time College Teachers with respect to their Job Satisfaction on the basis of their Stream.

h) To find out the differences among the Part-time College Teachers with respect to their Job Satisfaction on the basis of their Teaching Experience.

i) To find out the differences among the Part-time College Teachers with respect to their Job Satisfaction on the basis of their Income.

\section{Hypotheses of the Study}

H01: There is no high level of Job Satisfaction of Parttime College Teachers in the district of Hooghly, West Bengal.

H02: There is no significant difference between Male and Female Part-time College Teachers with respect to their Job Satisfaction.

H03: There is no significant difference between Rural and Urban Part-time College Teachers with respect to their Job Satisfaction.

H04: There is no significant difference between Rural Male and Female Part-time College Teachers with respect to their Job Satisfaction.

H05: There is no significant difference between Urban Male and Female Part-time College Teachers with respect to their Job Satisfaction.

H06: There is no significant difference between Rural Male and Urban Male Part-time College Teachers with respect to their Job Satisfaction.

H07: There is no significant difference between Rural Female and Urban Female Part-time College Teachers with respect to their Job Satisfaction.

H08: There is no significant difference between Married and Unmarried Part-Time College Teachers with respect to their job satisfaction.
H09: There is no significant difference among the Parttime College Teachers with respect to their Job Satisfaction on the basis of their Age.

H010: There is no significant difference among the Part-time College Teachers with respect to their Job Satisfaction on the basis of their level of Educational Qualification.

H011: There is no significant difference among the Part-time College Teachers with respect to their Job Satisfaction on the basis of their Stream.

H012: There is no significant difference between Arts and Science Stream Part-Time College Teachers with respect to their job satisfaction.

H013: There is no significant difference between Arts and Commerce Stream Part-Time College Teachers with respect to their job satisfaction.

H014: There is no significant difference between Science and Commerce Stream Part-Time College Teachers with respect to their job satisfaction.

H015: There is no significant difference among the Part-time College Teachers with respect to their Job Satisfaction on the basis of their Teaching Experience.

H016: There is no significant difference among the Part-time College Teachers with respect to their Job Satisfaction on the basis of their Income.

\section{Operational Definition of the Terms}

\subsection{Job Satisfaction}

Job Satisfaction refers to a mental state or feeling on which an employee's or an individual's tendency to do his/her work or job satisfactorily or dissatisfactorily is dependent [13]. Job Satisfaction of an individual depends on so many factors. Here, in this study the investigators have used this term 'Job Satisfaction' to mean that a feeling of satisfaction or dissatisfaction on the following dimensions [14]:
i. Working Condition
ii. Salary Status
iii. Understanding Between Colleagues
iv. Recognition by Others
v. Work Load
vi. Availability of Power and Status
vii. Promotion Opportunities

\subsection{Part-time College Teacher}

Here, in this study the investigators have used the term 'Part-time College Teacher' to mean that those teachers who were teaching part-time basis at different General Degree Colleges in the district of Hooghly, West Bengal [6].

\section{Methodology of the Study}

\subsection{Method of the Study}

The present study is Descriptive type in nature. The investigators have used Descriptive type survey method in the present study. Therefore, naturally the researchers have used different tools, techniques, strategies and 
methods of Descriptive survey type research to collect, analyze and interpret the data [15].

\subsection{Population of the Study}

All the Part-time college teachers in the district of Hooghly, West Bengal have been treated as population for the present study.

\subsection{Sample of the Study}

The investigators have selected only 110 Part-time college teachers among the all Part-time college teachers from 6 (six) selected General Degree Colleges which are situated in the district of Hooghly as a sample for the present study.

\subsection{Sampling Technique}

The Purposive sampling technique has been used in the selection of the sample.

\section{Tools of the Study}

In order to measure the Job Satisfaction of the Part-time college teachers, the researchers themselves have constructed a tool namely "Teachers' Job Satisfaction Scale" on the basis of seven important dimensions that are Working Conditions, Salary Status, Understanding between Colleagues, Recognition by Others, Work Load, Availability of Power and Status and Promotion Opportunities. The Scale consists of 60 items out of which 35 items are Positive and 25 items are Negative.

\subsection{Reliability and Validity of the Tool}

The present investigators in computing the reliability of the scale have adopted the test-retest method [15]. The value of Reliability of the tool is 0.92 . In measuring the validity of the tool, the Expert Judgment Method has been used by the investigators [15].

\section{Results and Discussion}

$\mathrm{HO}_{1}$ : There is no high level of Job Satisfaction of Parttime College Teachers in the district of Hooghly, West Bengal.
Techniques of Measuring the Level of Job Satisfaction

After all the items are scored, the scores of all the 60 items are added to obtain the total score of an individual Sample on the Job Satisfaction Scale. The range of the total score is $60-300$ as the Scale is constructed by 60 items on the basis of 5 point Likert Scale. Therefore, the Level of Job Satisfaction is considered from Score of the answers and is classified into 5 levels to the Best's Criteria (1977) as follows [15].

$$
\begin{aligned}
& \frac{\text { Highest Score }- \text { Lowest Score }}{\text { Number of Levels }} \\
& =\frac{300-60}{5}=\frac{240}{5}=48
\end{aligned}
$$

Table 1. Criteria for Understanding the Means of the Level of Job Satisfaction

\begin{tabular}{|c|c|}
\hline Range of Scores & Level of Job Satisfaction \\
\hline $60-108$ & Very Poor/Very Unsatisfied \\
\hline $109-156$ & Poor/Unsatisfied \\
\hline $157-204$ & Moderate \\
\hline $205-252$ & Good/Satisfied \\
\hline $253-300$ & Very Good/Very Satisfied \\
\hline
\end{tabular}

Table 2. Shows the Number, Mean and S.D of the Total Teachers

\begin{tabular}{|c|c|c|c|}
\hline Group & Number & Mean & S.D \\
\hline Teachers & 110 & 197.07 & 21.97 \\
\hline
\end{tabular}

Note: 60-108=Very Poor/Very Unsatisfied, 109-156=Poor/Unsatisfied, 157-204=Moderate, 205-252=Good/Satisfied and 253-300=Very Good/Very Satisfied.

From the Table 2, we can see that the obtained Mean Score of the Part-time College Teachers is 197.07 and S.D is 21.97. On the basis of the Best's Criteria, the obtained Mean Score of the Part-time College Teachers is 197.07 which fall under the range of Mean Scores of 157-204. It indicates that the level of Job Satisfaction of the Part-time College Teachers fall under the Moderate range group. Therefore, we can say that the level of Job Satisfaction of the Part-time College Teachers of the district of Hooghly, West Bengal is at Moderate level. It means that the Job Satisfaction of the Part-time College Teachers of the district of Hooghly is neither Unsatisfied nor Satisfied i.e. Moderate.

$\mathrm{HO}_{2}$ : There is no significant difference between Male and Female Part-time College Teachers with respect to their Job Satisfaction.

Table 3. Shows the difference between Male and Female Part-time College Teachers with respect to their Job Satisfaction

\begin{tabular}{|c|c|c|c|c|c|c|c|c|}
\hline Groups & N & Mean & S.D & Mean Difference & $\mathbf{S}_{\text {ED }}$ & df & t-value & Level of Significance \\
\hline Male Teacher & 72 & 197.88 & 24.01 & 2.32 & \multirow{2}{*}{4.42} & \multirow{2}{*}{108} & \multirow{2}{*}{0.52} & \multirow{2}{*}{ Not Significant at 0.05 Level } \\
\hline Female Teacher & 38 & 195.55 & 17.68 & & & & \\
\hline
\end{tabular}

From the Table 3, it is observed that the calculated ' $\mathrm{t}$ ' said that Male Part-time College Teachers are value (' $\mathrm{t}$ ' $=0.52)$ is less than the table value $(1.98$ at 0.05 level of significance). So, the result is not significant and it indicates that there is no significant difference between Male and Female Part-time College Teachers with respect to their Job Satisfaction. Hence, the Null hypothesis is accepted. But on the basis of their Mean Score, it can be comparatively more satisfied on their job than the Female Part-time College Teachers in the district of Hooghly.

$\mathrm{HO}_{3}$ : There is no significant difference between Rural and Urban Part-time College Teachers with respect to their Job Satisfaction.

Table 4. Shows the difference between Rural and Urban Part-time College Teachers with respect to their Job Satisfaction

\begin{tabular}{|c|c|c|c|c|c|c|c|c|}
\hline Groups & N & Mean & S.D & Mean Difference & S $_{\text {ED }}$ & df & t-value & Level of Significance \\
\hline Rural Teacher & 72 & 198.46 & 21.83 & 4.01 & 4.41 & \multirow{2}{*}{108} & 0.91 & Not Significant at 0.05 Level \\
\hline Urban Teacher & 38 & 194.45 & 22.29 & & & & \\
\hline
\end{tabular}


From the Table 4, it is observed that the calculated ' $\mathrm{t}$ ' value (' $t$ ' $=0.91$ ) is less than the table value (1.98 at 0.05 level of significance). So, the result is not significant and it indicates that there is no significant difference between Rural and Urban Part-time College Teachers with respect to their Job Satisfaction. Hence, the Null hypothesis is accepted. But on the basis of their Mean Score, it can be said that Rural Part-time College Teachers are comparatively more satisfied on their job than the Urban Part-time College Teachers in the district of Hooghly.

$\mathrm{HO}_{4}$ : There is no significant difference between Rural Male and Female Part-time College Teachers with respect to their Job Satisfaction.

Table 5. Shows the difference between Rural Male and Female Part-time College Teachers with respect to their Job Satisfaction

\begin{tabular}{|c|c|c|c|c|c|c|c|c|}
\hline Groups & $\mathbf{N}$ & Mean & S.D & Mean Difference & $\mathrm{S}_{\mathrm{ED}}$ & df & t-value & Level of Significance \\
\hline Rural Male Teacher & 46 & 200.41 & 23.39 & \multirow{2}{*}{5.41} & \multirow{2}{*}{5.36} & \multirow{2}{*}{70} & \multirow{2}{*}{1.01} & \multirow{2}{*}{$\begin{array}{c}\text { Not Significant at } 0.05 \\
\text { Level }\end{array}$} \\
\hline Rural Female Teacher & 26 & 195.00 & 18.70 & & & & & \\
\hline
\end{tabular}

From the Table 5, it is observed that the calculated ' $\mathrm{t}$ ' value (' $\mathrm{t}$ '=1.01) is less than the table value $(2.00$ at 0.05 level of significance). So, the result is not significant and it indicates that there is no significant difference between Rural Male and Female Part-time College Teachers with respect to their Job Satisfaction. Hence, the Null hypothesis is accepted. But on the basis of their Mean
Score, it can be said that Rural Male Part-time College Teachers are comparatively more satisfied on their job than the Rural Female Part-time College Teachers in the district of Hooghly.

$\mathrm{HO}_{5}$ : There is no significant difference between Urban Male and Female Part-time College Teachers with respect to their Job Satisfaction.

Table 6. Shows the difference between Urban Male and Female Part-time College Teachers with respect to their Job Satisfaction

\begin{tabular}{|c|c|c|c|c|c|c|c|c|}
\hline Groups & $\mathbf{N}$ & Mean & S.D & Mean Difference & $\mathrm{S}_{\mathrm{ED}}$ & df & t-value & Level of Significance \\
\hline Urban Male Teacher & 26 & 193.38 & 24.89 & \multirow{2}{*}{3.37} & \multirow{2}{*}{7.87} & \multirow{2}{*}{36} & \multirow{2}{*}{0.43} & \multirow{2}{*}{$\begin{array}{c}\text { Not Significant at } 0.05 \\
\text { Level }\end{array}$} \\
\hline Urban Female Teacher & 12 & 196.75 & 15.97 & & & & & \\
\hline
\end{tabular}

From the Table 6, it is observed that the calculated ' $\mathrm{t}$ ' Score, it can be said that Urban Female Part-time College value (' $\mathrm{t}$ ' $=0.43)$ is less than the table value $(2.03$ at 0.05 level of significance). So, the result is not significant and it indicates that there is no significant difference between Urban Male and Female Part-time College Teachers with respect to their Job Satisfaction. Hence, the Null hypothesis is accepted. But on the basis of their Mean

Teachers are comparatively more satisfied on their job than the Urban Male Part-time College Teachers in the district of Hooghly.

$\mathrm{HO}_{6}$ : There is no significant difference between Rural Male and Urban Male Part-time College Teachers with respect to their Job Satisfaction.

Table 7. Shows the difference between Rural Male and Urban Male Part-time College Teachers with respect to their Job Satisfaction

\begin{tabular}{|c|c|c|c|c|c|c|c|c|}
\hline Groups & $\mathbf{N}$ & Mean & S.D & Mean Difference & $\mathrm{S}_{\mathrm{ED}}$ & df & t-value & Level of Significance \\
\hline Rural Male Teacher & 46 & 200.41 & 23.39 & \multirow{2}{*}{7.03} & \multirow{2}{*}{5.87} & \multirow{2}{*}{70} & \multirow{2}{*}{1.19} & \multirow{2}{*}{$\begin{array}{c}\text { Not Significant at } 0.05 \\
\text { Level }\end{array}$} \\
\hline Urban Male Teacher & 26 & 193.38 & 24.89 & & & & & \\
\hline
\end{tabular}

From the Table 7 , it is observed that the calculated ' $\mathrm{t}$ ' value (' $\mathrm{t}$ '=1.19) is less than the table value $(2.00$ at 0.05 level of significance). So, the result is not significant and it indicates that there is no significant difference between Rural Male and Urban Male Part-time College Teachers with respect to their Job Satisfaction. Hence, the Null hypothesis is accepted. But on the basis of their Mean
Score, it can be said that Rural Male Part-time College Teachers are comparatively more satisfied on their job than the Urban Male Part-time College Teachers in the district of Hooghly.

$\mathrm{HO}_{7}$ : There is no significant difference between Rural Female and Urban Female Part-time College Teachers with respect to their Job Satisfaction.

Table 8. Shows the difference between Rural Female and Urban Female Part-time College Teachers with respect to their Job Satisfaction

\begin{tabular}{|c|c|c|c|c|c|c|c|c|}
\hline Groups & N & Mean & S.D & Mean Difference & $\mathbf{S}_{\text {ED }}$ & df & t-value & Level of Significance \\
\hline Rural Female Teacher & 26 & 195.00 & 18.70 & \multirow{2}{*}{1.75} & \multirow{2}{*}{6.25} & \multirow{2}{*}{36} & \multirow{2}{*}{0.28} & $\begin{array}{c}\text { Not Significant at } 0.05 \\
\text { Level }\end{array}$ \\
\cline { 1 - 4 } Urban Female Teacher & 12 & 196.75 & 15.97 & & & & \\
\hline
\end{tabular}

From the Table 8 , it is observed that the calculated ' $\mathrm{t}$ ' value (' $\mathrm{t}$ ' $=0.28)$ is less than the table value $(2.03$ at 0.05 level of significance). So, the result is not significant and it indicates that there is no significant difference between Rural Female and Urban Female Part-time College Teachers with respect to their Job Satisfaction. Hence, the Null hypothesis is accepted. But on the basis of their
Mean Score, it can be said that Urban Female Part-time College Teachers are comparatively more satisfied on their job than the Rural Female Part-time College Teachers in the district of Hooghly.

$\mathrm{HO}_{8}$ : There is no significant difference between Married and Unmarried Part-Time College Teachers with respect to their job satisfaction.

Table 9. Shows the difference between Married and Unmarried Part-Time College Teachers with respect to their job satisfaction

\begin{tabular}{|c|c|c|c|c|c|c|c|c|}
\hline Groups & $\mathbf{N}$ & Mean & S.D & Mean Difference & $\mathrm{S}_{\mathrm{ED}}$ & df & t-value & Level of Significance \\
\hline Married Teacher & 59 & 195.02 & 19.03 & \multirow{2}{*}{4.43} & \multirow{2}{*}{4.20} & \multirow{2}{*}{108} & \multirow{2}{*}{1.05} & \multirow{2}{*}{ Not Significant at 0.05 Level } \\
\hline Unmarried Teacher & 51 & 199.45 & 24.94 & & & & & \\
\hline
\end{tabular}

From the Table 9, it is observed that the calculated ' $t$ ' value (' $\mathrm{t}$ '=1.05) is less than the table value $(1.98$ at 0.05 level of significance). So, the result is not significant and it indicates that there is no significant difference between
Married and Unmarried Part-Time College Teachers with respect to their job satisfaction. Hence, the Null hypothesis is accepted. But on the basis of their Mean Score, it can be said that Unmarried Part-time College 
Teachers are comparatively more satisfied on their job than the Rural Married Part-time College Teachers in the district of Hooghly.
$\mathrm{HO}_{9}$ : There is no significant difference among the Parttime College Teachers with respect to their Job Satisfaction on the basis of their Age.

Table 10. Shows the difference among the Part-time College Teachers with respect to their Job Satisfaction on the basis of their Age

\begin{tabular}{|c|c|c|c|c|c|c|c|c|}
\hline Age & N & Mean & S.D & Mean Difference & $\mathbf{S}_{\text {ED }}$ & df & t-value & Level of Significance \\
\hline Below 30 Years & 52 & 196.38 & 21.88 & \multirow{2}{*}{1.31} & \multirow{2}{*}{4.21} & \multirow{2}{*}{108} & 0.31 & $\begin{array}{c}\text { Not Significant at } \\
0.05\end{array}$ \\
\cline { 1 - 4 } 30 and above 30 Years & 58 & 197.69 & 22.23 & & & \\
\hline
\end{tabular}

From the Table 10, it is observed that the calculated ' $\mathrm{t}$ ' value (' $\mathrm{t}$ ' $=0.31)$ is less than the table value $(1.98$ at 0.05 level of significance). So, the result is not significant and it indicates that there is no significant difference among the Part-time College Teachers with respect to their Job Satisfaction on the basis of their Age. Hence, the Null hypothesis is accepted. But on the basis of their Mean Score, it can be said that the Part-time College Teachers with the Age of 30 and above 30 Years are comparatively more satisfied on their job than the Part-time College Teachers with Age of below 30 Years in the district of Hooghly.

$\mathrm{HO}_{10}$ : There is no significant difference among the Parttime College Teachers with respect to their Job Satisfaction on the basis of their level of Educational Qualification.

Table 11. Shows the difference among the Part-time College Teachers with respect to their Job Satisfaction on the basis of their level of Educational Qualification

\begin{tabular}{|c|c|c|c|c|c|c|c|c|}
\hline Groups & $\mathbf{N}$ & Mean & S.D & Mean Difference & $\mathbf{S}_{\mathrm{ED}}$ & $\mathbf{d f}$ & t-value & Level of Significance \\
\cline { 1 - 4 } High Qualified Teacher & 48 & 198.00 & 23.80 & \multirow{2}{*}{1.65} & 4.24 & 108 & 0.39 & $\begin{array}{c}\text { Not Significant at } 0.05 \\
\text { Level }\end{array}$ \\
\cline { 1 - 5 } Low Qualified Teacher & 62 & 196.35 & 20.62 & & &
\end{tabular}

From the Table 11, it is observed that the calculated ' $\mathrm{t}$ ' value (' $\mathrm{t}$ ' $=0.39$ ) is less than the table value ( 1.98 at 0.05 level of significance). So, the result is not significant and it indicates that there is no significant difference among the Part-time College Teachers with respect to their Job Satisfaction on the basis of their level of Educational Qualification. Hence, the Null hypothesis is accepted. But on the basis of their Mean Score, it can be said that the High Qualified Part-time College Teachers are comparatively more satisfied on their job than the Low Qualified Part-time College Teachers in the district of Hooghly.

$\mathrm{HO}_{11}$ : There is no significant difference among the Parttime College Teachers with respect to their Job Satisfaction on the basis of their Stream.

Table 12. Shows the Number, Mean and S.D of the Part-time College Teachers of Different Streams

\begin{tabular}{|c|c|c|c|}
\hline Streams & $\mathrm{N}$ & Mean & S.D \\
\hline Arts & 65 & 198.86 & 23.62 \\
\hline Science & 29 & 197.38 & 18.69 \\
\hline Commerce & 16 & 189.25 & 19.94 \\
\hline Total & 110 & 197.07 & 21.97 \\
\hline
\end{tabular}

Table 13. Shows the difference among the Part-time College Teachers with respect to their Job Satisfaction on the basis of their Stream

\begin{tabular}{|c|c|c|c|c|}
\hline Sources of Variance & Sum of Squares & df & Mean Square & 594.918 \\
\hline Between Groups & 1189.837 & 2 & 480.781 \\
\hline Within Groups & 51443.581 & 107 & 1.23 \\
\hline Total & 52633.418 & 10 & \\
\cline { 1 - 3 }
\end{tabular}

At 0.05 level of Significance-3.09

\section{At 0.01 level of Significance-4.82.}

From the Table 13, it is observed that the calculated Fratio is 1.23 which is less than the table value at the both level of significance. Therefore, the result is not significant and we can say that there is no significant difference among the Part-time College Teachers with respect to their Job Satisfaction on the basis of their Stream. Hence, the null hypothesis is accepted. But on the basis of their Mean Score, it can be said that the Part-time College Teachers of Arts Stream are comparatively more satisfied on their job than the Part-time College Teachers of other Streams in the district of Hooghly. In the same way, it can also be said that the Part-time College Teachers of Commerce Stream are comparatively less satisfied on their job than the Part-time College Teachers of other Streams in the district of Hooghly.

$\mathrm{HO}_{12}$ : There is no significant difference between Arts and Science Stream Part-Time College Teachers with respect to their job satisfaction.

Table 14. Shows the difference between Arts and Science Stream Part-Time College Teachers with respect to their job satisfaction

\begin{tabular}{|c|c|c|c|c|c|c|c|c|}
\hline Streams & $\mathbf{N}$ & Mean & S.D & Mean Difference & $S_{E D}$ & df & t-value & Level of Significance \\
\hline Arts Teacher & 65 & 198.86 & 23.62 & \multirow{2}{*}{1.48} & \multirow{2}{*}{4.97} & \multirow{2}{*}{92} & \multirow{2}{*}{0.30} & \multirow{2}{*}{$\begin{array}{c}\text { Not Significant at } 0.05 \\
\text { Level }\end{array}$} \\
\hline Science Teacher & 29 & 197.38 & 18.69 & & & & & \\
\hline
\end{tabular}

From the Table 14, it is observed that the calculated ' $\mathrm{t}$ ' value (' $\mathrm{t}$ ' $=0.30)$ is less than the table value $(1.99$ at 0.05 level of significance). So, the result is not significant and it indicates that there is no significant difference between Arts and Science Stream Part-Time College Teachers with respect to their job satisfaction. Hence, the Null hypothesis is accepted. But on the basis of their Mean
Score, it can be said that the Part-time College Teachers of Arts Stream are comparatively more satisfied on their job than the Part-time College Teachers of Science Stream in the district of Hooghly.

$\mathrm{HO}_{13}$ : There is no significant difference between Arts and Commerce Stream Part-Time College Teachers with respect to their job satisfaction. 
Table 15. Shows the difference between Arts and Commerce Stream Part-Time College Teachers with respect to their job satisfaction

\begin{tabular}{|c|c|c|c|c|c|c|c|c|}
\hline Streams & $\mathbf{N}$ & Mean & S.D & Mean Difference & $\mathbf{S}_{\text {ED }}$ & df & t-value & Level of Significance \\
\hline Arts Teacher & 65 & 198.86 & 23.62 & \multirow{2}{*}{9.61} & \multirow{2}{*}{6.41} & 79 & \multirow{2}{*}{1.50} & \multirow{2}{*}{ Not Significant at 0.05 Level } \\
\hline Commerce Teacher & 16 & 189.25 & 19.94 & & & & & \\
\hline
\end{tabular}

From the Table 15, it is observed that the calculated ' $\mathrm{t}$ ' value (' $\mathrm{t}$ '=1.50) is less than the table value (1.99 at 0.05 level of significance). So, the result is not significant and it indicates that there is no significant difference between Arts and Commerce Stream Part-Time College Teachers with respect to their job satisfaction. Hence, the Null hypothesis is accepted. But on the basis of their Mean

Score, it can be said that the Part-time College Teachers of Arts Stream are comparatively more satisfied on their job than the Part-time College Teachers of Commerce Stream in the district of Hooghly.

$\mathrm{HO}_{14}$ : There is no significant difference between Science and Commerce Stream Part-Time College Teachers with respect to their job satisfaction.

Table 16. Shows the difference between Science and Commerce Stream Part-Time College Teachers with respect to their job satisfaction

\begin{tabular}{|c|c|c|c|c|c|c|c|c|}
\hline Streams & $\mathbf{N}$ & Mean & S.D & Mean Difference & S $_{\text {ED }}$ & df & t-value & Level of Significance \\
\hline Science Teacher & 29 & 197.38 & 18.69 & \multirow{2}{*}{8.13} & \multirow{2}{*}{5.96} & \multirow{2}{*}{43} & \multirow{2}{*}{1.36} & \multirow{2}{*}{ Not Significant at 0.05 Level } \\
\hline Commerce Teacher & 16 & 189.25 & 19.94 & & &
\end{tabular}

From the Table 16, it is observed that the calculated ' $\mathrm{t}$ ' value (' $\mathrm{t}$ '=1.36) is less than the table value $(2.02$ at 0.05 level of significance). So, the result is not significant and it indicates that there is no significant difference between Science and Commerce Stream Part-Time College Teachers with respect to their job satisfaction. Hence, the Null hypothesis is accepted. But on the basis of their Mean Score, it can be said that the Part-time College Teachers of Science Stream are comparatively more satisfied on their job than the Part-time College Teachers of Commerce Stream in the district of Hooghly.

$\mathrm{HO}_{15}:$ There is no significant difference among the Parttime College Teachers with respect to their Job Satisfaction on the basis of their Teaching Experience.

Table 17. Shows the Number, Mean and S.D of the Part-time College Teachers with the Different Teaching Experience

\begin{tabular}{|c|c|c|c|}
\hline Teaching Experience & $\mathrm{N}$ & Mean & S.D \\
\hline Below 4 Years & 69 & 195.35 & 23.21 \\
\hline Between 4 to 10 Years & 34 & 200.61 & 19.10 \\
\hline Above 10 Years & 7 & 196.71 & 20.54 \\
\hline Total & 110 & 197.07 & 21.97 \\
\hline
\end{tabular}

Table 18. Shows the difference among the Part-time College Teachers with respect to their Job Satisfaction on the basis of their Teaching Experience

\begin{tabular}{|c|c|c|c|}
\hline Sources of Variance & Sum of Squares & df & Mean Square \\
\hline Between Groups & 630.018 & 2 & 315.009 \\
\hline Within Groups & 52003.400 & 107 & 486.013 \\
\hline Total & 52633.418 & 109 & \\
\hline
\end{tabular}

At 0.05 level of Significance-3.09

At 0.01 level of Significance-4.82.

From the Table 18, it is observed that the calculated Fratio is 0.65 which is less than the table value at the both level of significance. Therefore, the result is not significant and we can say that there is no significant difference among the Part-time College Teachers with respect to their Job Satisfaction on the basis of their Teaching Experience. Hence, the null hypothesis is accepted. But on the basis of their Mean Score, it can be said that the Part-time College Teachers with the Teaching Experience of below 4 Years are comparatively less satisfied on their job than the other group of Part-time College Teachers in the district of Hooghly. In the same way, it can also be said that the Part-time College Teachers with the Teaching Experience of between 4 to 10

Years are comparatively more satisfied on their job than the other group of Part-time College Teachers in the district of Hooghly.

$\mathrm{HO}_{16}$ : There is no significant difference among the Parttime College Teachers with respect to their Job Satisfaction on the basis of their Income.

Table 19. Shows the Number, Mean and S.D of the Part-time College Teachers with the Different Income Group

\begin{tabular}{|c|c|c|c|}
\hline Income & $\mathrm{N}$ & Mean & S.D \\
\hline Below 10,000 & 72 & 198.88 & 23.31 \\
\hline Between 10,000 to 20,000 & 31 & 192.93 & 19.45 \\
\hline Above 20,000 & 7 & 196.71 & 20.21 \\
\hline Total & 110 & 197.07 & 21.97 \\
\hline
\end{tabular}

Table 20. Shows the difference among the Part-time College Teachers with respect to their Job Satisfaction on the basis of their Income

\begin{tabular}{|c|c|c|c|}
\hline Sources of Variance & Sum of Squares & df & Mean Square \\
\hline Between Groups & 374.670 & 2 & 187.335 \\
\hline Within Groups & 52258.748 & 107 & 488.400 \\
\hline Total & 52633.418 & 109 & 0.38 \\
\hline
\end{tabular}

At 0.05 level of Significance-3.09

At 0.01 level of Significance-4.82.

From the Table 20, it is observed that the calculated Fratio is 0.38 which is less than the table value at the both level of significance. Therefore, the result is not significant and we can say that there is no significant difference among the Part-time College Teachers with respect to their Job Satisfaction on the basis of their Income. Hence, the null hypothesis is accepted. But on the basis of their Mean Score, it can be said that the Part-time

College Teachers with the monthly Income of below 10,000 are comparatively more satisfied on their job than the other two income group of Part-time College Teachers in the district of Hooghly. In the same way, it can also be said that the Part-time College Teachers with the monthly Income of between 10,000 to 20,000 are comparatively less satisfied on their job than the other two income group of Part-time College Teachers in the district of Hooghly. 


\section{Major Findings of the Study}

1. It is found that the level of Job Satisfaction of the Part-time College Teachers of the district of Hooghly, West Bengal is at Moderate level. It means that the Job Satisfaction of the Part-time College Teachers of the district of Hooghly is neither Unsatisfied nor Satisfied i.e. Moderate.

2. It is found that there is no significant difference between Male and Female Part-time College Teachers with respect to their Job Satisfaction. But on the basis of their Mean Score, it can be said that Male Part-time College Teachers are comparatively more satisfied on their job than the Female Part-time College Teachers in the district of Hooghly.

3. It is found that there is no significant difference between Rural and Urban Part-time College Teachers with respect to their Job Satisfaction. But on the basis of their Mean Score, it can be said that Rural Part-time College Teachers are comparatively more satisfied on their job than the Urban Part-time College Teachers in the district of Hooghly.

4. It is found that indicates that there is no significant difference between Rural Male and Female Part-time College Teachers with respect to their Job Satisfaction. But on the basis of their Mean Score, it can be said that Rural Male Part-time College Teachers are comparatively more satisfied on their job than the Rural Female Parttime College Teachers in the district of Hooghly.

5. It is found indicates that there is no significant difference between Urban Male and Female Part-time College Teachers with respect to their Job Satisfaction. But on the basis of their Mean Score, it can be said that Urban Female Part-time College Teachers are comparatively more satisfied on their job than the Urban Male Part-time College Teachers in the district of Hooghly.

6. It is found indicates that there is no significant difference between Rural Male and Urban Male Part-time College Teachers with respect to their Job Satisfaction. But on the basis of their Mean Score, it can be said that Rural Male Part-time College Teachers are comparatively more satisfied on their job than the Urban Male Part-time College Teachers in the district of Hooghly.

7. It is found that there is no significant difference between Rural Female and Urban Female Part-time College Teachers with respect to their Job Satisfaction. But on the basis of their Mean Score, it can be said that Urban Female Part-time College Teachers are comparatively more satisfied on their job than the Rural Female Part-time College Teachers in the district of Hooghly.

8. It is found that that there is no significant difference between Married and Unmarried Part-Time College Teachers with respect to their job satisfaction. But on the basis of their Mean Score, it can be said that Unmarried Part-time College Teachers are comparatively more satisfied on their job than the Rural Married Part-time College Teachers in the district of Hooghly.

9. It is found that that there is no significant difference among the Part-time College Teachers with respect to their Job Satisfaction on the basis of their Age. But on the basis of their Mean Score, it can be said that the Part-time College Teachers with the Age of 30 and above 30 Years are comparatively more satisfied on their job than the Part-time College Teachers with Age of below 30 Years in the district of Hooghly.

10. It is found that that there is no significant difference among the Part-time College Teachers with respect to their Job Satisfaction on the basis of their level of Educational Qualification. But on the basis of their Mean Score, it can be said that the High Qualified Part-time College Teachers are comparatively more satisfied on their job than the Low Qualified Part-time College Teachers in the district of Hooghly.

11. It is found that that there is no significant difference among the Part-time College Teachers with respect to their Job Satisfaction on the basis of their Stream. But on the basis of their Mean Score, it can be said that the Parttime College Teachers of Arts Stream are comparatively more satisfied on their job than the Part-time College Teachers of other Streams in the district of Hooghly. In the same way, it can also be said that the Part-time College Teachers of Commerce Stream are comparatively less satisfied on their job than the Part-time College Teachers of other Streams in the district of Hooghly.

12. It is found that that there is no significant difference between Arts and Science Stream Part-Time College Teachers with respect to their job satisfaction. But on the basis of their Mean Score, it can be said that the Part-time College Teachers of Arts Stream are comparatively more satisfied on their job than the Part-time College Teachers of Science Stream in the district of Hooghly.

13. It is found that there is no significant difference between Arts and Commerce Stream Part-Time College Teachers with respect to their job satisfaction. But on the basis of their Mean Score, it can be said that the Part-time College Teachers of Arts Stream are comparatively more satisfied on their job than the Part-time College Teachers of Commerce Stream in the district of Hooghly.

14. It is found that there is no significant difference between Science and Commerce Stream Part-Time College Teachers with respect to their job satisfaction. But on the basis of their Mean Score, it can be said that the Part-time College Teachers of Science Stream are comparatively more satisfied on their job than the Parttime College Teachers of Commerce Stream in the district of Hooghly.

15. It is found that that there is no significant difference among the Part-time College Teachers with respect to their Job Satisfaction on the basis of their Teaching Experience. But on the basis of their Mean Score, it can be said that the Part-time College Teachers with the Teaching Experience of below 4 Years are comparatively less satisfied on their job than the other group of Part-time College Teachers in the district of Hooghly. In the same way, it can also be said that the Part-time College Teachers with the Teaching Experience of between 4 to 10 Years are comparatively more satisfied on their job than the other group of Part-time College Teachers in the district of Hooghly.

16. It is found that there is no significant difference among the Part-time College Teachers with respect to their Job Satisfaction on the basis of their Income. But on the basis of their Mean Score, it can be said that the Parttime College Teachers with the monthly Income of below 10,000 are comparatively more satisfied on their job than the other two income group of Part-time College Teachers 
in the district of Hooghly. In the same way, it can also be said that the Part-time College Teachers with the monthly Income of between 10,000 to 20,000 are comparatively less satisfied on their job than the other two income group of Part-time College Teachers in the district of Hooghly.

\section{Conclusion}

Job Satisfaction of employees is one of the most important determinant factors in the overall progress or improvement of any kind of institution. It is true that if the employees are satisfied with their job, they generally always try to give their better services in the developmental process of their institution or organization. And if the employees are not satisfied with their job, they lose their motivation to do work intrinsically [13]. As a result, they lose their commitment to their profession and their performance level goes down gradually that affects the overall improvement of the institution. Through the present study, it is found that the overall level of job satisfaction of Part-time College Teachers is neither satisfied nor unsatisfied i.e. moderate. It means that the Part-time college teachers of the district of Hooghly, West Bengal have some problems related to their job. Therefore, it is very necessary to take some effective measures or initiatives regarding their Working Conditions, Salary Status, Understanding between Colleagues, Recognition by Others, Work Load, Availability of Power and Status and Promotion Opportunities in order to increase the level of job satisfaction of them. In this matter, the Indian Education Commission (1964-66) also states that "nothing is more important than providing teacher's best professional preparation and creating satisfactory conditions of works in which they carefully are effective” [16].

Job satisfaction among college teachers is good not only for themselves but society as a whole. It increases productivity and classroom performance in the college. Wellbeing of any society depends upon the role played by the teacher. Teachers are the source of guidance in all the crucial steps in the academic life of the students. When teachers are satisfied with their job they can perform their responsibilities with more concentration and devotion [13]. Therefore, as most of the general degree colleges of West Bengal are being run by the Part-time college teachers, hence it is very urgent to think sincerely over the matter of job satisfaction of Part-time college teachers to improve the quality and standard of higher education in the state of West Bengal as well as in India [7].

\section{References}

[1] Department of Higher Education, Ministry of Human Resource Development (MHRD), Government of India, New Delhi, 2014.

[2] Annual Report (2011-12), University Grants Commission (UGC), New Delhi - 110 002, India.

[3] Marwan, T. Al-Zoubi. The Shape of the Relationship between Salary and Job Satisfaction: A Field Study. Far East Journal of Psychology and Business. Vol. 7, N. 3, Pp. 1-12, 2012.

[4] Annual Report (2012-13), Department of Higher Education, Government of West Bengal, Bikash Bhavan, Salt Lake City, Kolkata - 700 091, Saraswati Press.

[5] College and University Teachers' Association of Bengal (PTT), Notice Number-11, B-129, B.P. Township, Kolkata-700094, 2012.

[6] G.O. No. 751 Edn (CS) 5P-46/99 dated 21/09/2010, Department of Higher Education, Government of West Bengal, Bikash Bhavan, Salt lake, Kolkata-700091.

[7] Gupta, Dishari. A Comparative study of Job satisfaction and Organizational Commitment as work place values among PartTime Lecturers and Guest Lecturers of Government Aided Colleges in West Bengal. $3^{\text {rd }}$ International Conference on Psychology and Allied Sciences, Ministry of Social Justice and Empowerment, Govt. of India, New Delhi, 2014.

[8] Shamina, H. Impact of Job Satisfaction on Professional Commitment in Higher Education. International Interdisciplinary Research Journal. Vol. 2 (2), Pp. 1-11, 2014.

[9] Malik, Manju. A comparative Study on Job Satisfaction between Ad-Hoc Basis Teachers and Regular Teachers with reference to Degree Colleges of Kurukshetra. International Journal of Social Science \& Interdisciplinary, Vol. 2 (4), 52-60, 2013.

[10] Cashwell, Allison L. Factors affecting part-time faculty job satisfaction in the Colorado community college system. Unpublished doctoral dissertation, Colorado State University, 2009.

[11] Florencia López Bóo., Madrigal, Lucia., \& Pagés, Carmen. PartTime Work, Gender and Job Satisfaction: Evidence from a Developing Country. Journal of Development Studies, 46 (9), 1543-1571, 2009.

[12] Brown, James C. Full and part -time employee stress and job satisfaction at two upstate New York colleges. Unpublished doctoral dissertation, University of Phoenix, 2007.

[13] Katoch, Om Raj. Job Satisfaction among College Teachers: A Study on Government Colleges in Jammu (J \& K). Asian Journal of Research in Social Science \& Humanities, Vol. 2 Issue 4, 164180, 2012.

[14] Hoyt, J. E., Howell, S. L., \& Eggett, D. Dimensions of part-time faculty job satisfaction: Development and factor analysis of a survey instrument. Journal of Adult Education, 36 (2), pp. 23-34, 2007.

[15] Best, J.W. Research in Education, Eaglewood Cliffs, New Jersey, Prentice Hall, 1977.

[16] Report of the Kothari Education Commission (1964-66), Ministry of Education, Government of India. 